\title{
BIOCHEMICAL CHANGES IN RAT TESTIS DURING POSTNATAL MATURATION
}

\author{
L. L. EWING, A. R. MEANS,* \\ G. G. BEAMES, JR AND R. D. MONTGOMERY \\ Department of Physiology and Pharmacology, Oklahoma State University, \\ Stillwater, Oklahoma
}

(Received 29th December 1965)

\begin{abstract}
Summary. There is a paucity of information on quantitative changes occurring in chemical constituents of the testis during maturation. Total carbohydrate, total protein, total lipid, neutral lipid, phospholipid, saponifiable and non-saponifiable fractions of neutral lipid, and nonvolatile fatty acids of both the phospholipid and neutral lipid fractions were measured.

Testis weight was seen to increase at a rate greater than that noted for body weight from 28 days (time of testis descent) to 56 days (time of complete spermatogenesis). Changes in total protein and carbohydrate showed no definitive trends. A marked increase in total lipid was seen at 28 days which was reflected by increased phospholipid and neutral lipid values. The individual fatty acids showed some changes during maturation, but the most notable deviation was in the percentage composition of unsaturated fatty acids. The fatty acids of the neutral lipid fraction showed a marked increase in the percentage of fatty acids containing unsaturations, while those in the phospholipid fraction decreased in percentage containing unsaturations. These data are discussed concerning their possible relations to descent of the testis and initiation and maintenance of spermatogenesis.
\end{abstract}

\section{INTRODUCTION}

One of the most profound physiological changes occurring during the life of the male is the development of complete spermatogenesis. Although histological changes that take place during testicular maturation are well documented in the albino rat (Clermont \& Perey, 1957; Farris \& Griffith, 1949; Moore, 1939) and in man (Gruenwald, 1946; Charney, Constan, \& Meranze, 1952; de la Balze, Mancini, Arrellaga, Andrada, Vilar, Gurtman \& Davidson, 1960) little is known concerning the accompanying biochemical changes.

The importance of the following data stems from the fact that many workers are studying the effect of compounds affecting spermatogenesis without fully

\footnotetext{
* Present address: Department of Zoology, The University of Texas, Austin, Texas.
} 
understanding the events which initiate and support this process. It seems more logical in attempting to control spermatogenesis first to elucidate the way in which this type of cellular division takes place and then to take appropriate steps to control it. The object of these experiments was to lay the foundation for more definitive studies of the maturation process by providing information on the levels of biochemical constituents in the testis of the albino rat during postnatal development. The gross constituents studied were total carbohydrate, total protein and total lipid. The testis lipids were studied in greater detail by separating the total lipid fraction into some of its component subfractions (e.g. neutral lipid, phospholipid, individual fatty acids of these groups, etc.).

The dependence of fertility on dietary-essential fatty acids was noted by Burr \& Burr (1930) and Evans, Lepkovsky \& Murphey (1934). Aaes-Jorgensen \& Holman (1958) reported decreases in testis content of unsaturated fatty acids due to dietary deficiencies in essential fatty acids. The sterility induced by fatty acid deficiency was apparently due to degeneration of the seminiferous tubules since no changes were seen in the interstitial cells (Panos \& Finerty, 1954). Supplementary linoleic acid contributes to the return of normal spermatogenesis (Aaes-Jorgensen, Funch, Engel \& Dam, 1956), and cholesterol $(1 \%)$ added to an essential fatty acid deficient diet hastened the appearance of degeneration to 2 weeks from the 3-month periods previously observed (Pfiefer \& Holman, 1955). These observations further emphasize the importance of examining the testis fatty acids in a detailed manner.

\section{MATERIALS AND METHODS}

\section{Experimental design and pretreatment}

The animals used in these studies were male albino rats of the Holtzman strain. In each of five experiments, a number of animals were killed weekly, for a period of 8 weeks. Experiments were begun on 21-day-old rats. In order to obtain optimum amounts of tissue the number of animals necessarily varied from week to week as shown in Text-fig. 1 .

Testes were removed from rats, dissected free of tunica, weighed on a RollerSmith Torsion balance and pooled. The pooled tissue was minced with scissors and $600 \mathrm{mg}$ removed to be analysed for total protein and total carbohydrate. Lipid was extracted from the remainder of the minced tissue.

\section{Lipid extraction}

Lipids were extracted from the testicular tissue by the following modification of the method of Gray (1960). The tissue was minced with $25 \mathrm{vol} .(\mathrm{w} / \mathrm{v})$ of $\mathrm{CHCl}_{3}: \mathrm{CH}_{3} \mathrm{OH}(2: 1, \mathrm{v} / \mathrm{v})$ and allowed to stand overnight at $5^{\circ} \mathrm{C}$. Extracts were filtered on Buchner funnels and the residues were washed twice by resuspension in 1 vol. (w/v) $\mathrm{CHCl}_{3}: \mathrm{CH}_{3} \mathrm{OH}(2: 1, \mathrm{v} / \mathrm{v})$. The extracts and washings were combined, transferred to a separating funnel and washed with 1 vol. tap water gently stirred with a mechanical stirrer. After $2 \mathrm{hr}$ the $\mathrm{CHCl}_{3}: \mathrm{CH}_{3} \mathrm{OH}$ layer was removed and washed twice with $0.5 \mathrm{vol}$. of $0.5 \% \mathrm{KCl}$ solution. The washings were discarded and the $\mathrm{CHCl}_{3}: \mathrm{CH}_{3} \mathrm{OH}$ solution kept at $-20^{\circ} \mathrm{C}$ overnight to freeze out the remaining water, then filtered in the cold and dried 
over anhydrous $\mathrm{Na}_{2} \mathrm{SO}_{4}$. The solvent was removed in vacuo at $40^{\circ} \mathrm{C}$. The lipid was redissolved in $\mathrm{CHCl}_{3}$ and diluted to $10 \mathrm{ml}$ total volume. This solution was centrifuged to remove any $\mathrm{Na}_{2} \mathrm{SO}_{4}$ particles present. The clear to yellow supernatant was removed and $1.0 \mathrm{ml}$ aliquot plated into a tared planchet and dried overnight in a desiccator. The planchet was weighed at l-hr intervals until a constant weight was established, thus determining total lipid content gravimetrically.

\section{Silicic acid chromatography}

Total lipid was separated into neutral fats and phospholipids by silicic acid chromatography following the method of Borgstrom (1952). A $5 \mathrm{~g}$ column of silicic acid was used in all separations. The neutral fats were eluted with $100 \mathrm{ml}$ $\mathrm{CHCl}_{3}$ at a flow rate of $1 \mathrm{ml} / \mathrm{min}$. The phospholipids were eluted with $75 \mathrm{ml}$ $\mathrm{CHCl}_{3}: \mathrm{CH}_{3} \mathrm{OH}(4: 1, \mathrm{v} / \mathrm{v})$ followed by $75 \mathrm{ml} \mathrm{CH}_{3} \mathrm{OH}$. Solvents were removed in vacuo at $40^{\circ} \mathrm{C}$. Each residue was redissolved in $\mathrm{CHCl}_{3}$ to a final volume of $10 \mathrm{ml}$. Dry weights were determined as described above. In all cases recovery based on amount of total lipid put on the column was $100 \pm 3 \%$.

\section{Inorganic phosphate}

The inorganic phosphate $\left(\mathrm{P}_{\mathrm{i}}\right)$ content of the total and phospholipid fractions was determined using the Bottcher, Van Gent, \& Pries (1961) modification of the original procedure described by Bartlett (1959).

\section{Saponification}

Saponification of the neutral and phospholipid fractions into fatty acids and unsaponifiable lipids was accomplished with a modification of the technique described by Fairbairn (1955). The organic solvent was evaporated from a $5.0 \mathrm{ml}$ aliquot of each fraction with a stream of nitrogen. The lipid residue was dissolved in ether and washed twice with $5 \mathrm{ml}$ portions $0.5 \% \mathrm{Na}_{2} \mathrm{CO}_{3}$ to remove any non-esterified fatty acids. The aqueous solutions were discarded, ether evaporated and the lipid residue suspended in normal methanolic KOH. Saponification was accomplished by refluxing the suspensions under nitrogen for $4 \mathrm{hr}$ on a steam bath. At the end of this period the reflux condenser was removed and approximately half the methanol evaporated with a stream of nitrogen. Ten volumes $(\mathrm{v} / \mathrm{v})$ ether $(50 \mathrm{ml})$ were added to the cooled residues, the mixtures transferred quantitatively to separating funnels, and washed five times with $15 \mathrm{ml}$ aliquots glass distilled water. Saponifiable and unsaponifiable lipid concentrations were determined gravimetrically as previously described.

\section{Esterification of fatty acids}

The saponifiable portions from both neutral and phospholipid fractions were methylated with methanolic $\mathrm{BF}_{3}$ reagent (Applied Science Laboratories, Inc., State College, Pennsylvania) as described by Metcalf \& Schmitz (1961). The resulting esterified, non-volatile, fatty acid residues were dissolved in redistilled hexane before application to gas-liquid chromatography. 
Gas-liquid chromatography

The non-volatile, fatty acid methyl esters were analysed on a Barber-Coleman Model 15C gas chromatograph using a $6 \mathrm{ft}$ ( $4 \mathrm{~mm}$ i.d.) U-shaped glass column. Argon was the carrier gas and the instrument was equipped with a beta ionization detector.

The samples were first analysed on a column packed with Gas Chrom CLH (Applied Science Laboratories) (100-120 mesh) coated with ethylene glycol succinate (EGS) $(14.5 \%)$. The column temperature was $170^{\circ} \mathrm{C}$, the detector temperature was $205^{\circ} \mathrm{C}$ and the flash heater was operated at $195^{\circ} \mathrm{C}$. The anode voltage was maintained at 800 and the gas flow rate was $80 \mathrm{ml} / \mathrm{min}$. For aid in identification the samples were also run on a column packed with Gas Chrom CLH (100 to 120 mesh) coated with Apiezon L (20\%). Column temperature was $200^{\circ} \mathrm{C}$, detector $215^{\circ} \mathrm{C}$ and flash heater $225^{\circ} \mathrm{C}$. Anode voltage and gas flow were identical to those described above. The methyl esters were identified by comparison with the relative retention time (RRT) of known standards (Applied Science Laboratories) (relative to methyl palmitate) and by semilog plots of the RRT versus the number of carbon atoms in the acid (James \& Martin, 1956). These identifications were further checked by a $\log -\log$ plot of RRT on EGS versus RRT on Apiezon L. Percentage composition of the fatty acids in each sample was determined by multiplying the peak height times width at half peak height (Scott \& Grant, 1964).

\section{Total carbohydrate}

The $600 \mathrm{mg}$ freshly minced testis tissue not used in lipid extraction was homogenized in $3.0 \mathrm{ml}$ ice-cold $0.154 \mathrm{~N}-\mathrm{KCl}$. A manually operated, all-glass Ten Broeck homogenizer was used to prepare the tissue. Two $\mathrm{ml} 30 \% \mathrm{KOH}$ $(\mathrm{w} / \mathrm{v})$ were added to $0.5 \mathrm{ml}$ of the $20 \%(\mathrm{w} / \mathrm{v})$ testis homogenate and digested in a boiling water-bath for $20 \mathrm{~min}$. The solution was cooled and diluted to a final volume of $3.0 \mathrm{ml}$ with glass distilled water. Undiluted aliquots were used to assay for total carbohydrate employing the following modification of the method of Seifter, Dayton, Novic \& Muntwyler (1950). A 0.2\% anthrone solution (w/v) in concentrated $\mathrm{H}_{2} \mathrm{SO}_{4}$ was prepared and diluted with 0.5 vol. (w/v) glass distilled water with cooling. The procedure of Seifter et al. (1950) was then followed with the exception that $15 \mathrm{ml}$ diluted anthrone reagent were added to each tube instead of the prescribed $10 \mathrm{ml}$ undiluted reagent.

\section{Total protein}

One-tenth millilitre $20 \% \mathrm{KCl}$ homogenate was diluted to $10 \mathrm{ml}$ with glass distilled water. One-millilitre aliquots of this dilution were analysed for total protein using the Folin phenol method as described by Lowry, Rosebrough, Farr \& Randall (1951).

\section{RESULTS}

\section{Testis weight and body weight}

The body weights and testis weights of the animals used in the experiments are shown in Text-fig. 1. Each body-weight value represents the average weight 
in grams of twenty-one to 136 rats. The testis-weight data represent the average value of paired testes from the same number of animals. The actual number of rats represented by each point is also shown on Text-fig. 1. Standard deviation is represented by a vertical bar. The figure indicates that immediately following testis descent at 28 days, testis weight increases at a rate greater than that noted for body weight and continues to do so to 56 days of age.

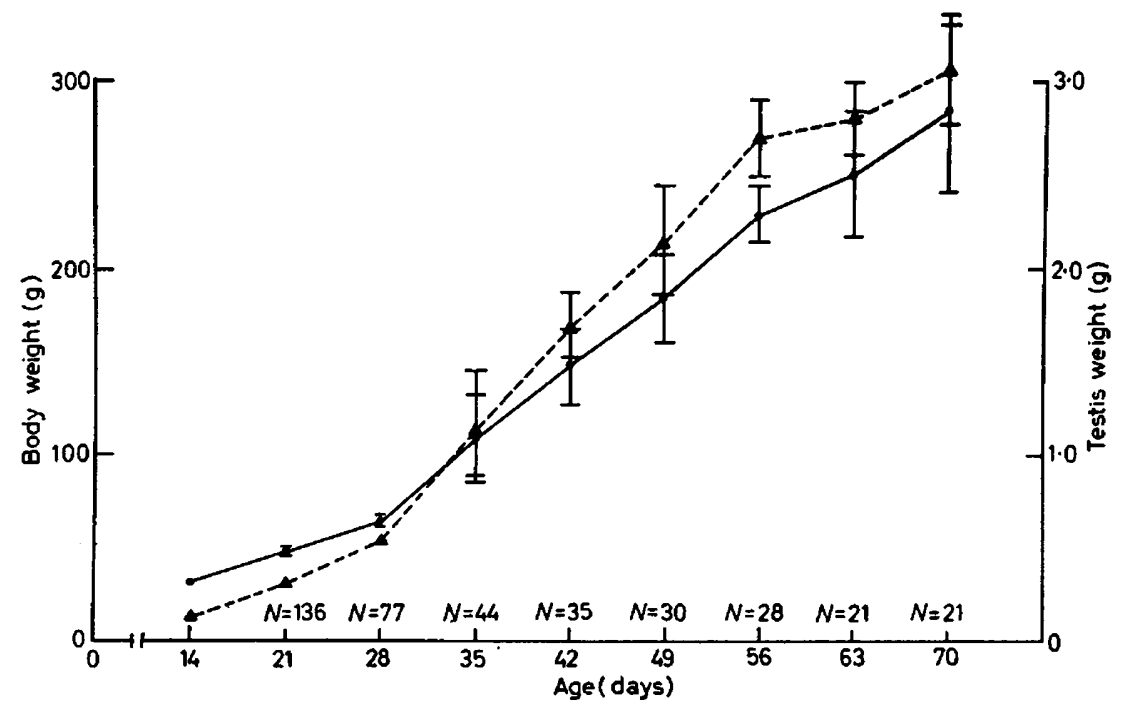

TEXT-FIG. 1. Changes in body weight $(\bullet)$ and testis weight $(\Delta)$ of rats during post-natal maturation. $\mathcal{N}$, Number of animals represented by each value.

TABLE 1

TOTAL PROTEIN $(\mathrm{mg} / \mathrm{g})$ AND TOTAL CARBOHYDRATE CONTENT $(\mathrm{mg} / \mathrm{g})$ OF RAT TESTIS DURING POST-NATAL MATURATION

\begin{tabular}{c|crr|ccc}
\hline Age (days) & \multicolumn{1}{|c|}{$x_{1}$} & \multicolumn{1}{|c|}{$x_{2}$} & \multicolumn{1}{c}{$\bar{x}$} & $x_{1}$ & $x_{2}$ & $x$ \\
\hline 21 & 68.8 & 93.5 & $81 \cdot 1$ & 1.09 & 1.75 & 1.42 \\
28 & 78.4 & 87.5 & 82.9 & 1.12 & 0.63 & 0.88 \\
35 & 72.5 & 88.5 & 80.5 & 1.22 & 2.13 & 1.67 \\
42 & 75.5 & 67.5 & 71.5 & 1.13 & 1.81 & 1.47 \\
49 & 80.0 & 102.5 & 91.2 & 1.22 & 1.81 & 1.51 \\
56 & 82.5 & 119.0 & 100.8 & 1.18 & 1.69 & 1.43 \\
63 & 78.5 & 90.0 & 84.2 & 1.48 & 4.06 & 2.73 \\
70 & - & 92.5 & 92.5 & - & 3.88 & 3.88 \\
\hline
\end{tabular}

$\bar{x}=$ Average of $x_{1}$ and $x_{2}$.

\section{Total protein and carbohydrate}

Total protein and carbohydrate content of the testis during maturation are shown in Table 1. Since these criteria were only analysed in the first and fifth experiments, the individual values are listed along with the average value $(\bar{x})$.

Total protein remains relatively constant from the onset of the experimental period to 35 days. A decline is noticed between 35 and 42 days followed by a 
pronounced increase to Day 56. Thereafter protein appears to return to earlier levels.

The total carbohydrate data show a relatively constant value for five of the eight experimental periods. Deviations from this value appear as a transient decrease at 28 days, the time corresponding to descent of the testes, and an increase at 63 and 70 days of age.

Perlman (1950) has shown that testis cholesterol is concentrated in the tubular elements and is probably most important in the earlier stages of spermatogenesis. The histochemical study by Wislocki (1949) on seasonal variations in the testis defined an increase in ketosteroids in the interstitial tissues during periods of active spermatogenesis. These observations indicated that the levels of protein and carbohydrate reported here might be examined to some advantage as the respective ratios of the unsaponifiable lipid fraction (notable constituents being cholesterol and steroids).

TABLE 2

LIPID GOMPONENTS OF RAT TESTES DURING POST-NATAL MATURATION

\begin{tabular}{|c|c|c|c|c|c|c|c|c|}
\hline \multirow{2}{*}{ Constituent } & \multicolumn{8}{|c|}{ Age (days) } \\
\hline & 21 & 28 & 35 & 42 & 49 & 56 & 63 & 70 \\
\hline Total lipid (mg/g testis) & $\begin{array}{r}13 \cdot 6 \\
\pm 1 \cdot 1\end{array}$ & $\begin{array}{r}16 \cdot 8 \\
\pm 1 \cdot 6\end{array}$ & $\begin{array}{r}12 \cdot 8 \\
\pm 1 \cdot 4\end{array}$ & $\begin{array}{r}12 \cdot 5 \\
\pm 2 \cdot 0\end{array}$ & $\begin{array}{r}12 \cdot 3 \\
\pm 2 \cdot 0\end{array}$ & $\begin{array}{r}11 \cdot 1 \\
\pm 1 \cdot 7\end{array}$ & $\begin{array}{r}12 \cdot 3 \\
\pm 2 \cdot 4\end{array}$ & $\begin{array}{r}14.2 \\
\pm 0.9\end{array}$ \\
\hline$P_{1}$ total $(\mu \mathrm{g} / \mathrm{g}$ testis $)$ & $\begin{array}{r}400 \cdot 1 \\
\pm 35 \cdot 2\end{array}$ & $\begin{array}{r}619 \cdot 0 \\
\pm 81 \cdot 6\end{array}$ & $\begin{array}{r}465 \cdot 5 \\
\pm 46 \cdot 8\end{array}$ & $\begin{array}{r}431 \cdot 1 \\
\pm 46 \cdot 4\end{array}$ & $\begin{array}{r}427 \cdot 7 \\
\pm 33 \cdot 9\end{array}$ & $\begin{array}{r}403 \cdot 8 \\
\pm 40 \cdot 2\end{array}$ & $\begin{array}{r}445 \cdot 3 \\
\pm 54 \cdot 4\end{array}$ & $\begin{array}{r}491 \cdot 1 \\
\pm 129 \cdot 3\end{array}$ \\
\hline Phospholipid (mg/g testis) & $\begin{array}{r}9.5 \\
\pm 1.2\end{array}$ & $\begin{array}{r}11.9 \\
\pm 2 \cdot 0\end{array}$ & $\begin{array}{r}9 \cdot 1 \\
\pm 1 \cdot 7\end{array}$ & $\begin{array}{r}10 \cdot 6 \\
\pm 1.5\end{array}$ & $\begin{array}{r}10 \cdot 1 \\
\pm 1 \cdot 2\end{array}$ & $\begin{array}{r}8 \cdot 2 \\
\pm 1 \cdot 3\end{array}$ & $\begin{array}{r}9 \cdot 7 \\
\pm 2 \cdot 2\end{array}$ & $\begin{array}{r}10.6 \\
\pm 0.8\end{array}$ \\
\hline $\begin{array}{l}P_{1} \text { of phospholipid ( } \mu \mathrm{g} / \mathrm{g} \\
\text { testis) }\end{array}$ & $\begin{array}{r}349 \cdot 2 \\
\pm 44 \cdot 7\end{array}$ & $\begin{array}{r}651 \cdot 6 \\
\pm 51 \cdot 8\end{array}$ & $\begin{array}{r}429 \cdot 5 \\
\pm 67 \cdot 7\end{array}$ & $\begin{array}{r}346 \cdot 9 \\
\pm 39 \cdot 4\end{array}$ & $\begin{array}{r}360 \cdot 3 \\
\pm 29 \cdot 8\end{array}$ & $\begin{array}{r}326 \cdot 5 \\
\pm 30 \cdot 5\end{array}$ & $\begin{array}{r}396 \cdot 6 \\
\pm 40 \cdot 0\end{array}$ & $\begin{array}{r}341 \cdot 6 \\
\pm 36 \cdot 5\end{array}$ \\
\hline Neutral lipid (mg/g testis) & $\begin{array}{r}4 \cdot 6 \\
\pm 0 \cdot 9\end{array}$ & $\begin{array}{r}5 \cdot 1 \\
\pm 0.5\end{array}$ & $\begin{array}{r}3 \cdot 8 \\
\pm 0.6\end{array}$ & $\begin{array}{r}2 \cdot 9 \\
\pm 0 \cdot 3\end{array}$ & $\begin{array}{r}3 \cdot 5 \\
\pm 0 \cdot 4\end{array}$ & $\begin{array}{r}3 \cdot 1 \\
\pm 0.5\end{array}$ & $\begin{array}{r}3.3 \\
\pm 0.5\end{array}$ & $\begin{array}{r}3.9 \\
\pm 0.5\end{array}$ \\
\hline $\begin{array}{l}\text { Saponifiable fraction } \\
\text { (mg/g testis) }\end{array}$ & $\begin{array}{r}2.5 \\
\pm 0.2\end{array}$ & $\begin{array}{r}2 \cdot 2 \\
\pm 0 \cdot 2\end{array}$ & $\begin{array}{r}1.7 \\
\pm 0.3\end{array}$ & $\begin{array}{r}0.9 \\
\pm 0.9\end{array}$ & $\begin{array}{r}1.6 \\
\pm 0.3\end{array}$ & $\begin{array}{r}1.4 \\
\pm 0.2\end{array}$ & $\begin{array}{r}1.2 \\
\pm 0.1\end{array}$ & $\begin{array}{r}1.4 \\
\pm 0.6\end{array}$ \\
\hline $\begin{array}{l}\text { Unsaponifiable fraction } \\
\text { (mg/g testis) }\end{array}$ & $\begin{array}{r}2 \cdot 6 \\
\pm 0.4 \\
\end{array}$ & $\begin{array}{r}2.4 \\
\pm 0.3 \\
\end{array}$ & $\begin{array}{r}2 \cdot 0 \\
\pm 0 \cdot 4 \\
\end{array}$ & $\begin{array}{r}1 \cdot 7 \\
\pm 0 \cdot 2 \\
\end{array}$ & $\begin{array}{r}1 \cdot 9 \\
\pm 0 \cdot 2 \\
\end{array}$ & $\begin{array}{r}1.7 \\
\pm 0.3 \\
\end{array}$ & $\begin{array}{r}2.0 \\
\pm 0.4 \\
\end{array}$ & $\begin{array}{r}1.8 \\
\pm 0.3 \\
\end{array}$ \\
\hline PL $/$ NL ratio & $2 \cdot 08$ & $2 \cdot 34$ & $2 \cdot 38$ & $3 \cdot 64$ & $2 \cdot 87$ & $2 \cdot 70$ & $2 \cdot 95$ & $2 \cdot 71$ \\
\hline Unsap./Sap. ratio & $1 \cdot 03$ & $1 \cdot 11$ & $1 \cdot 15$ & $1 \cdot 77$ & $1 \cdot 19$ & $1 \cdot 23$ & $1 \cdot 66$ & $1 \cdot 24$ \\
\hline PL/Unsap.L. ratio & $3 \cdot 69$ & $4 \cdot 91$ & $4 \cdot 60$ & $6 \cdot 33$ & $6 \cdot 02$ & $4 \cdot 87$ & 4.93 & $5 \cdot 93$ \\
\hline
\end{tabular}

Each value represents mean \pm sample standard deviation where $n=5$.

Expression of the protein data as the ratio total protein/unsaponifiable lipid indicates that the 21-day value $(31.43)$ is approximately maintained in the 28-day value (34.26). However, a greater increase is seen at 35 days (40.86), followed by subsequent increases at 42 days $(42.56), 49$ days (49.03) and 56 days (59.24). A large decrease is seen at 63 days (42.96), followed by a return to the previous levels at 70 days $(51.68)$. The relative increase in the protein levels expressed as a function of unsaponifiable lipid levels closely parallels the rapid growth-rate increase seen following testis descent at 28 days.

Total carbohydrate expressed as a function of the unsaponifiable lipid fraction reflects the trends seen in the total carbohydrate data (Table 1). 


\section{Lipid}

The various lipid components are shown in Table 2. Values are expressed as the mean \pm sample standard deviation. Total lipid shows an increase at 28 days, a slight decrease at 56 days and a slight increase at 70 days with the intervening values remaining quite constant. The inorganic phosphate $\left(\mathbf{P}_{\mathbf{i}}\right)$ of total lipid and phospholipid parallel total lipid in all cases. The increase seen at 28 days in total lipid levels is reflected in an increase in phospholipid values. At 35 days, the level returns to near the 21-day value and again increases at 42 days, to be maintained in the 49-day observation. A marked decrease at 56 days is followed by increases at 63 and 70 days.

TABLE 3

NON-VOLATILE FATTY ACIDS OF NEUTRAL LIPID FRACTION OF RAT TESTIS DURING POST-NATAL MATURATION (AVERAGE PERCENTAGE OF FATTY ACIDS SEPARATED BY GLC)

\begin{tabular}{|c|c|c|c|c|c|c|c|c|}
\hline \multirow{2}{*}{$\begin{array}{l}\text { Carbon No.: } \\
\text { No. double } \\
\text { bonds }\end{array}$} & \multicolumn{8}{|c|}{ Neutral lipid fraction } \\
\hline & 21 & 28 & 35 & 42 & 49 & 56 & 63 & 70 \\
\hline $\begin{array}{l}9 \\
10 \\
11: 1 \\
12 \\
13(12: 2) \\
14 \\
14: 1 \\
15 \\
15: 1 \\
16 \\
16: 1 \\
17 \\
17: 1 \\
18 \\
18: 1 \\
18: 2\end{array}$ & $\begin{array}{c}\text { Tr. } \\
1.34 \\
\text { Tr. } \\
3.84 \\
0.60 \\
5.80 \\
\text { Tr. } \\
0.38 \\
\text { Tr. } \\
25.34 \\
2.06 \\
0.30 \\
0.52 \\
7.34 \\
24.42 \\
11.64\end{array}$ & $\begin{array}{c}\text { Tr. } \\
1.60 \\
\text { Tr. } \\
2.76 \\
0.54 \\
5.64 \\
\text { Tr. } \\
0.54 \\
\text { Tr. } \\
24.02 \\
4.04 \\
0.23 \\
0.60 \\
7.12 \\
22.06 \\
11.05\end{array}$ & $\begin{array}{c}\text { Tr. } \\
2 \cdot 53 \\
\text { Tr. } \\
1 \cdot 13 \\
0 \cdot 75 \\
3.94 \\
\text { Tr. } \\
0 \cdot 60 \\
\text { Tr. } \\
26 \cdot 92 \\
4 \cdot 61 \\
0 \cdot 21 \\
0 \cdot 74 \\
6.21 \\
21.39 \\
11.70\end{array}$ & $\begin{array}{c}\text { Tr. } \\
0.92 \\
\text { Tr. } \\
0.72 \\
0.20 \\
3.04 \\
\text { Tr. } \\
0.46 \\
\text { Tr. } \\
24.31 \\
5.68 \\
0.28 \\
0.57 \\
5.02 \\
21.76 \\
13.35\end{array}$ & $\begin{array}{c}\text { Tr. } \\
0.37 \\
\text { Tr. } \\
0 \cdot 61 \\
0 \cdot 23 \\
2.94 \\
\text { Tr. } \\
0 \cdot 34 \\
\text { Tr. } \\
24 \cdot 04 \\
6.54 \\
0 \cdot 27 \\
0 \cdot 58 \\
4.80 \\
22 \cdot 88 \\
14.81\end{array}$ & $\begin{array}{c}\text { Tr. } \\
0.72 \\
\text { Tr. } \\
0.58 \\
1.14 \\
3.93 \\
\text { Tr. } \\
0.42 \\
\text { Tr. } \\
27.31 \\
6.82 \\
0.22 \\
0.47 \\
4.04 \\
20.25 \\
12.68\end{array}$ & $\begin{array}{c}\text { Tr. } \\
0 \cdot 43 \\
\text { Tr. } \\
0 \cdot 40 \\
0.77 \\
3 \cdot 28 \\
\text { Tr. } \\
0 \cdot 22 \\
\text { Tr. } \\
28 \cdot 42 \\
7 \cdot 10 \\
0.20 \\
0 \cdot 59 \\
4.86 \\
23 \cdot 60 \\
14.59\end{array}$ & $\begin{array}{r}\text { Tr. } \\
2 \cdot 33 \\
\text { Tr. } \\
0 \cdot 39 \\
0.59 \\
3.38 \\
\text { Tr. } \\
0 \cdot 41 \\
\text { Tr. } \\
26.54 \\
7.81 \\
0.12 \\
0.66 \\
3.86 \\
23 \cdot 12 \\
14.54\end{array}$ \\
\hline $\begin{array}{l}\text { UNK A }(20: 3) \\
\text { UNK B }(20: 4) \\
\text { UNK C }(22: 5)\end{array}$ & $\begin{array}{l}\text { Tr. } \\
3 \cdot 39 \\
6 \cdot 34\end{array}$ & $\begin{array}{l}\text { Tr. } \\
4.41 \\
8.75\end{array}$ & $\begin{array}{l}\text { Tr. } \\
4 \cdot 61 \\
6 \cdot 50\end{array}$ & $\begin{array}{l}\text { Tr. } \\
3 \cdot 88 \\
8 \cdot 70\end{array}$ & $\begin{array}{l}\text { Tr. } \\
3 \cdot 48 \\
8 \cdot 19\end{array}$ & $\begin{array}{l}\text { Tr. } \\
2 \cdot 70 \\
8 \cdot 15\end{array}$ & $\begin{array}{l}\text { Tr. } \\
2 \cdot 78 \\
6.88\end{array}$ & $\begin{array}{l}\text { Tr. } \\
3 \cdot 35 \\
9 \cdot 72\end{array}$ \\
\hline $\begin{array}{l}\text { Total } \\
\text { Total unsat. } \\
\text { fatty acids }>4 \%\end{array}$ & $\begin{array}{l}93 \cdot 3 \% \\
47 \cdot 85 \%\end{array}$ & $\begin{array}{l}93 \cdot 4 \\
50 \cdot 31\end{array}$ & $91 \cdot 8$ & 53.37 & $90 \cdot 1$ & $50 \cdot 60$ & 54.95 & $96 \cdot 8$ \\
\hline
\end{tabular}

Identified on gas-liquid chromatography; quantitation described in text. Each value represents average of five replicates. Tr., Trace.

The neutral lipid fraction shows slightly elevated values at 21 and 28 days and slightly decreased values at 35 and 42 days followed by a return to the 35-day value which is maintained thereafter. The data for saponifiable and unsaponifiable matter in Table 2 relate to subfractions of the neutral lipid. Both subfractions generally follow the same trend as the neutral lipid.

Since no definitive changes were seen in the lipid constituents it was decided to express the values as the ratios: phospholipid-neutral lipid (PL/NL) and unsaponifiable lipid-saponifiable lipid (Unsap.L./Sap.L.) and phospholipidunsaponifiable lipid (PL/Unsap.L.) and to note any changes in the relationships 
of these ratios. It is apparent that phospholipids are present in greater concentration than neutral lipids and this difference is seen to increase to Day 42, decrease at Day 49 and remain relatively constant to Day 70 . The Unsap.L./ Sap.L. ratio shows that the concentration of unsaponifiable lipids is only slightly higher than the saponifiable fraction and that this level difference increases to 42 days. This occurs concurrently with the noted rise in the PL/NL ratio. It is also apparent that following the rise in Unsap.L./Sap.L. ratio, a distinct decline occurs and the values then remain relatively constant to the Day 70 observation with the exception of the increase at 63 days. The noted decline in $\mathrm{PL} / \mathrm{NL}$ ratio at 49 days will be seen to occur concurrently with decline in Unsap.L./Sap.L. ratio.

TABLE 4

NON-VOLATILE FATTY AGIDS OF PHOSPHOLIPID FRACTION OF RAT TESTIS DURING POST-NATAL MATURATION (AVERAGE PERCENTAGE OF FATTY AGIDS SEPARATED BY GLC)

\begin{tabular}{|c|c|c|c|c|c|c|c|c|}
\hline \multirow{2}{*}{$\begin{array}{l}\text { Carbon No.: } \\
\text { No. double } \\
\text { bonds }\end{array}$} & \multicolumn{8}{|c|}{ Phospholipid fraction } \\
\hline & 21 & 28 & 35 & 42 & 49 & 56 & 63 & 70 \\
\hline $\begin{array}{l}10 \\
11: 1 \\
12 \\
13 \\
14 \\
14: 1 \\
15 \\
15: 1 \\
16 \\
16: 1 \\
17 \\
17: 1 \\
18 \\
18: 1 \\
18: 2 \\
20: 1\end{array}$ & $\begin{array}{r}0.60 \\
0.19 \\
0.17 \\
1.35 \\
0.46 \\
0.33 \\
0.20 \\
2.41 \\
30.74 \\
1.25 \\
0.49 \\
1.09 \\
9.72 \\
22.86 \\
3.92 \\
1.16\end{array}$ & $\begin{array}{r}0 \cdot 30 \\
0 \cdot 10 \\
0 \cdot 19 \\
0 \cdot 57 \\
0 \cdot 49 \\
0 \cdot 14 \\
0 \cdot 26 \\
0 \cdot 19 \\
34 \cdot 26 \\
1 \cdot 11 \\
0 \cdot 44 \\
0 \cdot 39 \\
10 \cdot 92 \\
24 \cdot 48 \\
4.21 \\
0.52\end{array}$ & $\begin{array}{r}1 \cdot 17 \\
0.39 \\
0 \cdot 28 \\
2 \cdot 72 \\
0 \cdot 46 \\
0 \cdot 53 \\
0.43 \\
1.77 \\
32 \cdot 24 \\
1 \cdot 13 \\
0.65 \\
0.91 \\
8.73 \\
16.78 \\
5.70 \\
-\end{array}$ & $\begin{array}{r}0.61 \\
0.25 \\
0.16 \\
1.46 \\
0.47 \\
0.34 \\
0.35 \\
0.47 \\
39.80 \\
0.86 \\
0.65 \\
0.59 \\
10.27 \\
13.76 \\
5.20 \\
-\end{array}$ & $\begin{array}{r}0.45 \\
0 \cdot 18 \\
0 \cdot 18 \\
0.90 \\
0 \cdot 65 \\
0.22 \\
0 \cdot 22 \\
0.66 \\
37.60 \\
1.16 \\
0.63 \\
0.58 \\
10.86 \\
15.61 \\
6.02 \\
-\end{array}$ & $\begin{array}{r}0.69 \\
0.66 \\
0.11 \\
2.12 \\
0.24 \\
0.51 \\
0.23 \\
1.15 \\
35.88 \\
0.67 \\
0.45 \\
0.61 \\
9.00 \\
13.67 \\
6.05 \\
-\end{array}$ & $\begin{array}{r}1.08 \\
0.28 \\
0.13 \\
1.98 \\
0.48 \\
0.58 \\
0.23 \\
1.43 \\
37.15 \\
0.89 \\
0.46 \\
0.77 \\
8.33 \\
15.22 \\
5.87 \\
-\end{array}$ & $\begin{array}{r}0.44 \\
0.19 \\
0.16 \\
0.98 \\
0.39 \\
0.30 \\
0.16 \\
1.97 \\
38.99 \\
0.92 \\
0.63 \\
0.48 \\
9.47 \\
14.56 \\
6.42 \\
-\end{array}$ \\
\hline $\begin{array}{l}\text { UNK A }(20: 3) \\
\text { UNK B }(20: 4) \\
\text { UNK C }(22: 5)\end{array}$ & $\begin{array}{r}1 \cdot 33 \\
15 \cdot 14 \\
4 \cdot 38\end{array}$ & $\begin{array}{r}1 \cdot 05 \\
11 \cdot 24 \\
4 \cdot 14\end{array}$ & $\begin{array}{r}1 \cdot 25 \\
15.53 \\
6.02\end{array}$ & $\begin{array}{r}1 \cdot 49 \\
13 \cdot 23 \\
7 \cdot 18\end{array}$ & $\begin{array}{r}0 \cdot 86 \\
11.80 \\
8.97\end{array}$ & $\begin{array}{r}1 \cdot 36 \\
13 \cdot 07 \\
10 \cdot 15\end{array}$ & $\begin{array}{r}1 \cdot 27 \\
10 \cdot 86 \\
6.98\end{array}$ & $\begin{array}{l}1 \cdot 11 \\
9 \cdot 97 \\
5 \cdot 70\end{array}$ \\
\hline $\begin{array}{l}\text { Total } \\
\text { Total unsat. } \\
\text { fatty acids }>4 \%\end{array}$ & $\begin{array}{l}97 \cdot 8 \% \\
46 \cdot 30 \%\end{array}$ & $\begin{array}{l}95 \cdot 7 \\
44 \cdot 07\end{array}$ & $96 \cdot 7$ & $39 \cdot 37$ & $42 \cdot 40$ & 42.94 & $94 \cdot 0$ & $92 \cdot 8$ \\
\hline
\end{tabular}

Identified on gas-liquid chromatography; quantitation described in text. Each value represents average of five replications.

Expression of phospholipid data as a ratio of the unsaponifiable lipid fraction (PL/Unsap.L.) as seen in Table 2 reveals an increase from 21 to 42 days, and a levelling off thereafter.

\section{Fatty acids}

The fatty acids tentatively identified from the neutral and phospholipid fractions by gas-liquid chromatography and the percentage of the total saponifiable fraction that each represents are listed in Table 3 (neutral lipid) and 
Table 4 (phospholipid). Three were listed as unknown. These three were compared with the equivalent chain length of the fatty acids of bovine and porcine testes reported by Holman \& Hofstetter (1965) and are thought to be $\mathrm{C}_{20: 3}, \mathrm{C}_{20: 4}$ and $\mathrm{C}_{22: 5}$, respectively. Of the nineteen acids listed, eighteen were seen to be identical. $n$-Nonanoic $\left(\mathrm{C}_{9: 0}\right)$ appeared in the neutral lipid fraction in trace amounts at all time periods but not in the phospholipids. A 20-carbon mono-unsaturated acid appeared at 21 and 28 days in the phospholipids but was not observed in the neutral lipids. Three of the nineteen acids, $\mathrm{C}_{16: 0}$, $\mathrm{C}_{18: 1}$, and $\mathrm{C}_{18: 2}$, comprise about $60 \%$ of the total neutral lipid fatty acids. In the phospholipid fraction, however, the most abundant acids are $\mathrm{C}_{16: 0}, \mathrm{C}_{18: 1}$ and unK $B\left(\mathrm{C}_{20: 4}\right)$, together contributing 65 to $70 \%$ of the total. The tentatively identified fatty acids represent from 89 to $98 \%$ of the total fatty acids in all cases.

Trends seen in individual neutral lipid fatty acids include the following: $\mathrm{C}_{12: 0}$ decreases throughout the experimental period, though after Day 42, the changes are slight; $\mathrm{C}_{14: 0}$ decreases to Day 42 ; increases at Day 56 and is maintained at slightly lowered levels to Day $70 ; \mathrm{C}_{16: 1}$ increases with each observation from Day 21 to Day $70 ; \mathrm{C}_{18: 0}$ is seen to decrease throughout the 8-week period while $\mathrm{C}_{18: 2}$ and UNK $\mathrm{C}_{22: 5}$ are observed to increase.

While the weekly variations of the phospholipid fatty acids seem to be more erratic than those of the neutral lipid acids, trends are evident in the decreases in $\mathrm{C}_{18: 1}$ and in the total increase in $\mathrm{C}_{18: 2}$ for the 8-week experimental period. UNK B exhibits a transient decrease at Day 28, a graded decrease from the 35-day value to Day 49 and an upturn at 56 days which is not maintained in the following two observations. Summation of percentage unsaturated fatty acids present (those comprising more than $4 \%$ of the total) is shown in Tables 3 and 4 and may be seen to decrease in the phospholipid fraction (Table 4) while increasing in neutral lipid fraction (Table 3 ) throughout the test period.

\section{DISCUSSION}

\section{Testis weight and body weight}

Testis and body weight both exhibit the typical S-shaped growth curve with the most rapid increase in both criteria occurring between 28 and 56 days of age as shown in Text-fig. 1. During this period, it is seen that the body-growth rate is exceeded by the rate of increase in testis weight. In all five experiments the testes were observed to descend into the scrotum about the 28th day. That testicular descent and the onset of the period of most rapid growth occur at the same time is not surprising since it is well documented that scrotal testes function optimally at the lower temperature of the scrotum (Moore, 1923). The end of the most rapid growth at 56 days corresponds closely to the time observed by Clegg (1960) for the establishment of full spermatogenesis in 90 to $100 \%$ of the seminiferous tubules in the testis of the albino rat. Hence the greatest testiculargrowth rate is associated with the period of sexual development.

\section{Total protein and carbohydrate}

The most apparent change in protein content (Table 1 ) is seen as an increase from 42 to 56 days of age. A slight decrease is then noted at 63 days though the 
level does not drop to the previous values. Since Clermont \& Perey (1957) reported that mature sperm cells are first seen in the rat testis at 35 days of age and in view of Clegg's (1960) observation it seems possible that the increase in protein content from 42 to 56 days may be attributed to an increase in sperm cell number. The following slight decrease could then be explained by movement of the first wave of spermatozoa out of the testis into the epididymis and continued production of sperm cells at a somewhat reduced rate. Preliminary data from our laboratory on DNA content of the testis indicates that it follows the same trend as the protein, lending support to this suggestion.

The ratio of total protein-unsaponifiable lipid is noted to increase at 35 days and this rise occurs 1 week following the decreased carbohydrate-unsaponifiable lipid ratio. The temporal relationship of the decreased ratio of total carbohydrate-unsaponifiable lipid introduces the possibility that decreased carbohydrate content is brought about by some constituent of the unsaponifiable lipid fraction. This could imply an increased carbohydrate utilization due to androgen stimulation. This is supported in that Ewing \& Eik-Nes (unpublished data) observed a direct correlation between testosterone secretion rate and glucose uptake by the isolated, perfused rabbit testis. They suggested that increased testosterone secretion in some way stimulates glucose uptake by the testis.

\section{Lipid}

Table 2 shows a transient increase at 28 days in the total lipid data which is reflected by an increase in phospholipid, $P_{i}$ of phospholipid, and $P_{i}$ of total lipid. This does not support the data of McEnery \& Nelson (1953) who indicate that organic phosphorous compounds in the testis of rats between 10 and 180 days of age show no change in lipid phosphorus throughout the test period, though there was a slight increase at 20 days of age. The observed 28-day increase in lipid constituents corresponds with testis descent and immediately precedes the period of accelerated growth seen in Text-fig. 1. Whether this change has occurred as a build-up preparatory to descent or is concomitant with or the result of descent is not known.

Though the comparative magnitude of changes in the various lipid values are not definitive, expression of certain of the data as ratios of some other fraction exhibits some interesting changes. The $\mathrm{PL} / \mathrm{NL}$ ratio indicates a comparative increase in importance of the phospholipids at about 42 days of age (Table 2). That this may be related to androgenic effect or cholesterol levels is seen in the relative increase in importance of the unsaponifiable lipid fraction compared with the saponifiable fraction (Table 2) which occurs as a gradual increase, climaxing concomitantly with the rise seen in the $\mathrm{PL} / \mathrm{NL}$ ratio. Horchner, Kassenar \& Querido (1963) noted that testosterone propionate stimulated the metabolism of phospholipids in the seminal vesicle of castrate male rats. Incorporation of ${ }^{32} \mathrm{P}$ into the phosphatides was noted to increase significantly $24 \mathrm{hr}$ following administration of the steroid. This observation would seem to lend support to the suggestion that increased PL/NL ratio may result from an increase in relative importance of the cholesterol- and androgencontaining unsaponifiable fraction of the neutral lipids. The notable rise in the phospholipid-unsaponifiable lipid ratio seen at 42 days might also result from a 
stimulation of this type. The subsequent decreases seen in values for the two ratios at 49 days (PL/NL) and 56 days (PL/Unsap.L.) may indicate that the stimulation occurs as a surge during the onset of spermatogenesis followed by a decline to maintenance level.

As previously noted, Perlman (1950) has indicated that cholesterol in the testis seems to be present in highest concentration in the tubular elements and that it is apparently more prevalent in the earlier cell-types seen in spermatogenesis. There may exist a relation between the cholesterol portion of the unsaponifiable fraction and the phospholipid levels.

An enlightening study on these points would include measurement of circulating and testicular levels of testosterone, and testicular levels of cholesterol during maturation.

\section{Fatty acids}

The predominant fatty acids of both neutral and phospholipid fractions were those acids which occur in largest quantity in most tissues; palmitate $\left(\mathrm{G}_{16: 0}\right)$ and oleate $\left(\mathrm{C}_{18: 1}\right)$. The fact that eighteen of the nineteen acids identified were the same in each fraction may indicate the utility of the technique used for identification and the types of fatty acids present in the testes.

The three fatty acids not tentatively identified were compared with the equivalent chain lengths of the fatty acids of bovine and porcine testis as identified by Holman \& Hofstetter (1965) and are thought to be $\mathrm{C}_{20: 3}$ and $\mathrm{C}_{20: 4}$ for UNK $\mathrm{A}$ and UNK B. UNK $\mathrm{C}$ compares favourably with their $\mathrm{C}_{22: 5}$. The percentages seen for rat do not agree well with those for bull and boar testes. Comparison of the percentage of unsaturated fatty acids in the phospholipid and neutral lipid fractions indicates certain species differences. Degree of unsaturation in fatty acids of phospholipids versus neutral lipids is about the same in porcine testis ( $\mathrm{PL}=46.5 \% ; \mathrm{NL}=46.8 \%$ ), whereas in the bull testis, neutral lipid fatty acids are less unsaturated than phospholipid fatty acids ( $\mathrm{PL}=43.8 \%, \mathrm{NL}=26.3 \%$ ). The rat testis phospholipid and neutral lipid fractions demonstrate similar degrees of unsaturated fatty acid content at 21 days ( $\mathrm{NL}=47.85 \%$ unsaturated; $\mathrm{PL}=46.30 \%$ unsaturated), but at 70 days, (after sexual maturity), the phospholipid fatty acids have decreased by about $26 \%$, while the neutral lipid fatty acids have increased by about $22 \%$ of the total fatty acids observed.

Increases in linoleic acid $\left(\mathrm{G}_{18: 2}\right)$ content (Table 3 ) are seen to occur during maturation in both the phospholipid and neutral lipid fractions. However, total unsaturates $(>4 \%)$ are seen to increase by $22 \%$ in neutral lipid fatty acids, but decrease by $26 \%$ in phospholipid fatty acids (Table 3 ). An absolute relationship between unsaturated fatty acid content and the onset of spermatogenesis is not evident from this data, unless the increases in $\mathrm{C}_{18: 2}$ seen in both the neutral lipid and phospholipid fraction are indicative of such a relationship.

The data presented indicate that more detailed studies of chemical changes during maturation of the testis are necessary. Studies are presently underway to determine the relative importance of the various energy producing pathways during maturation. Changes in the metabolic incorporation of ${ }^{14} \mathrm{C}$ from labelled precursors into the fractions reported herein are under study. Data from these 
type studies will aid in determining temporal relationships with growth, the varying importance of certain areas of metabolic activity and, in general, a more completely defined portrait of occurrences involved in the initiation and maintenance of spermatogenesis.

\section{ACKNOWLEDGMENTS}

This investigation was supported in part by Oklahoma State University Agricultural Experiment Station No. 1191 and National Institutes of Health, U.S.P.H.S. HD-00636. The authors are indebted to Mrs Judith Terrell for excellent technical assistance.

\section{REFERENCES}

Aaes-Jorgensen, E., Funch, J. P., Engel, P. F. \& Dam, H. (1956) The role of fat in the diet of rats. 9. Influence on growth and histological findings of diets with hydrogenated arachis oil or no fat, supplemented with linoleic acid or raw skim milk and of crude casein compared with vitamin test casein. Br. F. Nutr. 10, 292.

Aaes-Jorgensen, E. \& Holman, R. T. (1958) Essential fatty acid deficiency. I. Content of polyenoic acids in testes and heart as an indicator of E.F.A. status. 7. Nutr. 65, 633.

Bartlett, G. R. (1959) Phosphorous assay in column chromatography. 7. biol. Chem. 234, 466.

Borgstrom, B. (1952) Investigations on lipid separation methods. Separation of phospholipids from neutral fat and fatty acids. Acta physiol. scand. 25, 101.

Bottcher, C. J. F., van Gent, C. M. \& Pries, C. (1961) A rapid and sensitive sub-micro phosphorous determination. Analytica chim. Acta, 24, 203.

BURr, G. O. \& BURR, M. M. (1930) On the nature and role of the fatty acids essential in nutrition. 7. biol. Chem. 86, 587.

Charny, C. W., Conston, A. S. \& Meranze, D. R. (1952) Development of testis. Fert. Steril. 3, 461.

CLEGG, E. J. (1960) The age at which male rats become fertile. F. Reprod. Fert. 1, 119.

Clermont, Y. \& Perey, B. (1957) Quantitative study of the cell population of the seminiferous tubules in immature rats. Am. F. Anat. 100, 241.

de la Balze, F. A., Mancini, R. A., Arrellaga, F., Andrada, J. A., Vilar, O., Gurtman, A. I. \& Davidson, O. W. (1960) Puberal maturation of the normal human testis. A histologic study. 7. clin. Endocr. Metab. 20, 266.

Evans, H. M., Lepkovsky, S. \& MURPhy, E. A. (1934) Vital need of the body for certain unsaturated fatty acids. VI. Sterility on fat-free diets. 7 . biol. Chem. 106, 445.

Fatrbairn, D. (1955) Lipids of the female reproductive tract of Ascaris lumbricoides. Can. F. Biochem. Physiol. 33, 31.

FARRIs, E. J. \& GRIFFrth, J. Q. (1949) The rat in laboratory investigation. Lippincott, Philadelphia.

Gray, G. M. (1960) The phospholipids of ox spleen with special reference to the fatty acid and fatty aldehyde compositions of the lecithin and kephalin fractions. Biochem. 7. 77, 82.

Gruenwald, P. (1946) Structure of the testis in infancy and in childhood. Arch. Path. 42, 35.

Holman, R. T. \& Hofstetter, H. H. (1965) The fatty acid composition of the lipids from bovine and porcine reproductive tissues. F. Am. Oil Chem. Soc. 42, 540.

Horchner, P., KassenaAr, A. A. H. \& Querido, A. (1963) The influence of testosterone (-propionate) on the phospholipid metabolism in the seminal vesicle of castrated male rats. Acta physiol. pharm. néerl. 12, 163.

JAMEs, A. T. \& MARTiN, A. J. P. (1956) Gas liquid chromatography: the separation and identification of the methyl esters of saturated and unsaturated acids from formic acid to n-octadecanoic acid. Biochem. 7. 63, 144.

Lowry, O. H., Rosebrough, N. J., Farr, A. L. \& Randall, R. J. (1951) Protein measurement with the Folin phenol reagent. $\mathcal{F}$. biol. Chem. 193, 265.

MCENERY, W. B. \& NeLSON, W. O. (1953) Organic phosphorous compounds in the testis of the rat at various ages. Endocrinology, 52, 93.

Metcalf, L. D. \& Schmrtz, A. A. (1961) The rapid preparation of fatty acid esters for gas chromatographic analysis. Analyt. Chem. 33, 363.

Moore, C. R. (1939) Biology of the testis. Sex and Internal Secretions, 2nd edn. Eds. E. Allen, C. H. Danforth and E. A. Doisey. Williams \& Wilkins, Baltimore. 
Moore, C. R. (1923) On the relationship of the germinal epithelium to the position of the testis. Anat. Rec. 25, 142.

PANos, T. C. \& FinerTy, J. C. (1954) Effects of a fat-free diet on growing male rats with special reference to the endocrine system. F. Nutr. 54, 315.

Peifer, J. J. \& Holman, R. T. (1955) Essential fatty acids, diabetes and cholesterol. Archs Biochem. Biophys. 57, 520.

PerLman, P. L. (1950) The functional significance of testis cholesterol in the rat: 1. Effects of hypophysectomy and cryptorchidism. Endocrinology, 46, 341.

ScotT, R. P. W. \& GrANT, D. W. (1964) Measurement of elution peaks in gas-liquid chromatography. Analyst, 89, 179.

Seifter, S., DAyton, S., Novic, B. \& Muntwyler, E. (1950) The estimation of glycogen with the anthrone reagent. Archs Biochem. Biophys. 25, 191.

WisLockI, G. B. (1949) Seasonal changes in the testes, epididimides and seminal vesicles of deer investigated by histochemical methods. Endocrinology, 44, 167. 